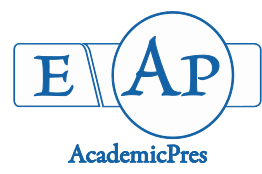

\title{
Morphological Performance of Onion under Exogenous Treatments of $\mathrm{GA}_{3}$
}

\author{
Md. Dulal SARKAR*, Mohammad SHAHJAHAN, Khairul KABIR, \\ Abu Yousuf SHIHAB, A.N.M. SAYEM
}

\author{
Sher-e-Bangla Agricultural University, Faculty of Agriculture, Department of Horticulture, Dhaka-1207, Bangladesh; \\ dulalsau_121@yahoo.com (*correspondingauthor); shahjahanhort@sau.edu.bd;kabir@sau.edu.bd; shihab.dc12@gmail.com; \\ sayemreader@gmail.com
}

\begin{abstract}
The present study was conducted to assess the morphological response of onion plants to different $\mathrm{GA}_{3}$ levels $(0,20,40$ and $60 \mathrm{ppm}$ ). The factor levels of $\mathrm{GA}_{3}$ were applied during transplanting by root soaking and foliar spray at 30 and 60 days after transplanting. The gibberellic acid had a great effect on increasing plant height $(46.50 \mathrm{~cm})$, shoot biomass $\left(641.67 \mathrm{~g} \mathrm{~m}^{-2}\right)$, bulb biomass $\left(1125.00 \mathrm{~g} \mathrm{~m}^{-2}\right)$ and also dry matter accumulation in onion plants under the effect of $60 \mathrm{ppm}$ compared to control. Plants grown up without $\mathrm{GA}_{3}$ application were shorter than those grown with $\mathrm{GA}_{3}$ spray where the lowest plant height $(34.67 \mathrm{~cm})$ was remarked. The leaf number $(11.43)$ was considerably increased when $60 \mathrm{ppm} \mathrm{GA}_{3}$ was used as the growth promoter factor in comparison to control. The plants attain minimum fresh biomass at harvesting time in the shoot $\left(441.67 \mathrm{~g} \mathrm{~m}^{-2}\right)$ and bulb $\left(641.67 \mathrm{~g} \mathrm{~m}^{-2}\right)$ grown in control plot. Considerably (41.63\%) more dry shoot biomass accumulation was recorded in $60 \mathrm{ppm} \mathrm{GA} 3$ treated plants in comparison with the control at harvesting stages. Insignificant effect by all concentration of $\mathrm{GA}_{3}$ was found in bulb length, fresh root biomass and dry root biomass. Thus, the use of $60 \mathrm{ppm} \mathrm{GA}_{3}$ can be recommend for onion production due to the significantly increased of the fresh bulb biomass with about $42.96 \%$ over control.
\end{abstract}

Keywords: Allium cepa; bulb crop; growth regulators; morpho-physiology

\section{Introduction}

Globally, onion (Allium cepa L.) is an important crop that needs proper agricultural management in order to achieve a great flavour and to increase the production in regard with the consumer's demand (Sharma et al., 2015). It is the main spice crop rather than vegetable and therapeutic in Bangladesh (BBS, 2015). This bulbous crop sparingly holds the first position in terms of production among the spice crops (BBS, 2015). Bangladesh is producing about 1,052 metric tons of onion, over 300 thousand acres of land, with the average yield about 3.33 metric tons per acre (BBS, 2015). Bangladeshi farmers grow onion during both winter and summer seasons, following traditional methods. Although the area and production of onion have been increased compared to an earlier period, still the average yield is lower as compared to much other onion producing neighbouring countries and it may be impossible to accomplish the domestic demand, due to growing population (BBS, 2015).
Plant growth regulators have a potential role in modern agriculture (Ashraf et al., 2010) and have been known as key element for vegetative growth and bulbing (Rahman et al., 2004; Ouzounidou et al., 2011). Besides stimulating the growth processes, they also affect seed development, organ elongation, senescence and control of flowering time (Yamaguchi, 2008; Yu et al., 2009; Ghoname et al., 2011). $\mathrm{GA}_{3}$ play a vital role to vigorous growth, that promoted the total plant length of onion by $35 \%$ of the control and also increased the number of leaves, fresh and dry weight significantly (Ouzounidou et al., 2011). Thus $\mathrm{GA}_{3}$ have the promoter effect on the growth and development of bulb crops, as well as the total yield (Hye et al., 2002; Islam et al., 2007; Amal and Hegazi, 2009).

The option of more expansion of the area under onion cultivation seems unlikely because of intense crop competition. Improving the production of onion using some modern agricultural practices need to be considered. Regarding this, the yield of onion can be increased by using plant growth regulators. Moreover, analysis of morphological features of a plant would be a feasible 
technique for modelling growth and development of onion plants that is an obligate prerequisite to understanding the behavioural response.

The present study aimed to improve the onion production from the scientific and economic point of view. Therefore, an attempt was taken in the present study to evaluate the effect of $\mathrm{GA}_{3}$ on morphological characters of onion and also to test standardized concentrations of $\mathrm{GA}_{3}$.

\section{Materials and Methods}

\section{Plant material and site description}

The variety 'BARI Onion-1' was tested at the horticulture farm of Sher-e-Bangla Agricultural University, Bangladesh in $24.09^{\circ} \mathrm{N}$ latitude and $90.26^{\circ} \mathrm{E}$ longitude with an elevation of $8.20 \mathrm{~m}$ from sea level. The experimental field is under the subtropical climate characterized by scanty precipitation during the interval from October to March. 'BARI Onion-1' is a winter variety and comparatively less susceptible to pest and diseases. Plants were maintained in the open environment under natural sunlight. The soil of the experimental site is in loam textural class (Table 1).

\section{Plant growth characters}

Data was collected on plant growth features (e.g. plant height, leaf number, root length, bulb length and bulb diameter), fresh biomass assimilation (e.g. fresh root biomass, fresh shoot biomass and fresh bulb biomass) and dry biomass accumulation (e.g. dry root biomass, dry shoot biomass and dry bulb biomass).

\section{The experimental design}

The experiment was conducted by Randomized Complete Block Design with three replications. The factor levels of $\mathrm{GA}_{3}$ studied were as follows: (i) Control: $0 \mathrm{ppm}$ (G0), (ii) $20 \mathrm{ppm}\left(\mathrm{G}_{20}\right)$, (iii) $40 \mathrm{ppm}\left(\mathrm{G}_{40}\right)$ and (vi) $60 \mathrm{ppm}$ $\left(\mathrm{G}_{60}\right)$. These three levels of $\mathrm{GA}_{3}$ along with control were applied three times: first one during transplanting by root soaking, while the second and third phase applications were done at 30 and 60 days after transplanting.

\section{Growing conditions}

Required seeds were sown in the seedbed on 15 October 2014 and transplanted into the experimental field on 30 November 2014 at a spacing of $15 \mathrm{~cm} \times 10 \mathrm{~cm}$. After transplanting, the plants were irrigated by watering cane to saturation. Fertilizers were used at the rate of usual range for commercial production at $60,30,80,20,1.5,0.7 \mathrm{~kg} \mathrm{ha}^{-1}$ for
N, P, K, S, Zn, B, and cowdung respectively (FRG, 2012). Intercultural operations were furnished for proper growth and development of the crop. Bulbs were harvested after 90 days after transplanting.

\section{Statistical analysis}

Analysis of variance was performed in order to assess the significance of the effect of $\mathrm{GA}_{3}$ in onion. Tukey's HSD tests were used to determine variances between each treatment where $\mathrm{P}<0.05$ was considered as significant. Statistical analyses were carried out using IBM SPSS Statistics version 20 .

\section{Results and Discussion}

\section{Plant growth characters}

A significant result by using $\mathrm{GA}_{3}$ on onion was observed for plant height (Fig. 1), for the number of leaves plant ${ }^{-1}$ (Fig. 2), root length and bulb diameter (Table 2). Conversely, no significant variance was found in bulb length with different doses of $\mathrm{GA}_{3}$ (Table 2). With slightly higher the doses, plant height gradually changed.

The maximum plant height $(46.50 \mathrm{~cm})$ was recorded under the effect of 60 ppm GA $\mathrm{GA}_{3}$. Plants grown up without $\mathrm{GA}_{3}$ application were shorter than those grown with $\mathrm{GA}_{3}$ spray and this increasing growth pattern was observed in the concentration of 20 to $60 \mathrm{ppm}$. The lowest plant height $(34.67 \mathrm{~cm})$ remarked on the control, which means without $\mathrm{GA}_{3}$ (Fig. 1).

According to Fig. 1, the $\mathrm{GA}_{3}$ effect regarding the plant height was small, but changed with some different doses. The increase in plant height can be attributed to the effects of gibberellic acid in comparison to the control, which is consistent with previous results when $\mathrm{GA}_{3}$ promoted the plant height in onion (Shukla et al., 2010; Ouzounidou et al., 2011; Sisodia et al., 2012; Nagwa et al., 2013), in sweet pepper (Pérez-Jiménez et al. 2015), combination of $\mathrm{GA}_{3}$ and 4-CPA regulate plant height in tomato (Choudhury et al., 2013). Similar with this study, a significantly gradual increasing trend of plant height was noticed using $\mathrm{GA}_{3}$ in gladiolus (Sarkar et al., 2014) and tuberose (Sultana et al., 2016) and in addition $\mathrm{GA}_{3}$ promoted plant growth and its secondary metabolite production in purple coneflower (Jones et al., 2009). Exogenously applied gibberellic acid increased plant height and, subsequently, enhanced dry weight (Sharma et al., 1998). In the hereby experiment, the increased plant heights was due to the regulatory effect of

Table 1. Physical and chemical properties of the experimental soil as observed prior to experimentation

\begin{tabular}{|c|c|c|c|c|c|}
\hline \multicolumn{6}{|c|}{ Physical properties and mechanical fractions } \\
\hline Sand \% $(2.0-0.05 \mathrm{~mm})$ & Silt \% (0.05-0.002 mm) & Clay \% (<0.002 mm) & Particle density $\left(\mathrm{g} \mathrm{ccG}^{-1}\right)$ & Bulk density $\left(\right.$ g ccG $\left.^{-1}\right)$ & Porosity \\
\hline 39.42 & 41.11 & 22.31 & 2.59 & 1.47 & 43.24 \\
\hline \multicolumn{6}{|c|}{ Soil properties: Chemical analysis } \\
\hline $\mathrm{pH}(1: 2.5$ soil-water $)$ & Organic matter $(\%)$ & Total N (\%) & Available $\mathrm{P}\left(\mu \mathrm{g} \mathrm{g}^{-1}\right)$ & Exchangeable K (meq) & Available $S\left(\mu \mathrm{gg}^{-1}\right)$ \\
\hline 5.90 & 0.85 & 0.07 & 19.00 & 0.07 & 20.72 \\
\hline \multicolumn{6}{|c|}{ Soil properties: Chemical analysis } \\
\hline Available Fe $\left(\mu \mathrm{gg}^{-1}\right)$ & Available $\mathrm{Zn}\left(\mu \mathrm{gg}^{-1}\right)$ & Available $\mathrm{Mg}\left(\mu \mathrm{gg}^{-1}\right)$ & Available $\mathrm{Na}\left(\mu \mathrm{gg}^{-1}\right)$ & \multicolumn{2}{|c|}{ Available B $\left(\mu \mathrm{gg}^{-1}\right)$} \\
\hline 227 & 4.45 & 0.83 & 0.31 & \multicolumn{2}{|c|}{0.92} \\
\hline
\end{tabular}


$\mathrm{GA}_{3}$ that induce active cell division, proline accumulation, and endogenous hormones IAA, $\mathrm{GA}_{3}$ and cytokinins in the apical meristem, resulting to the vigorous vegetative growth of onion plants. These results were also an agreement with the findings of that- $\mathrm{GA}_{3}$ normally act by signalling the removal of proteins that repress growth, thus promoting cell proliferation and elongation (Olszewski et al., 2002; Ubeda Tomas et al., 2009; Taiz and Zeiger, 2010).

The number of leaves in onion plants was higher (11.43) under $60 \mathrm{ppm} \mathrm{GA}_{3}$ treated plants than those grown in other concentration or in control (Fig. 2). The leaf number was considerably increased when $60 \mathrm{ppm} \mathrm{GA} 3$ was used as the growth promoter factor in comparison to control (Fig. 2). This concentration of $\mathrm{GA}_{3}$ might have more ability to balance the hormonal activity in plants. Subsequently, increases in cell division might have a prodigious effect in the larger number of leaves production. $\mathrm{GA}_{3}$ leads to increased vegetative growth of plants with vigorous shoots, with increased number of leaves and it has been revealed earlier for onion (Ud-Deen et al., 2005; Yamaguchi, 2008; Yu et al., 2009; Ouzounidou et al., 2011; Nagwa et al., 2013), eddo (Ud-deen, 2009), gladiolus (Sarkar et al., 2014) and tuberose (Sultana et al., 2016).

Regarding the root parameter of the onion, the longest root $(6.10 \mathrm{~cm})$ was recorded gradually in the increased concentration up to $60 \mathrm{ppm} \mathrm{GA}_{3}$, whereas the shortest roots $(3.80 \mathrm{~cm})$ were in control (Table 2).

At the same time, $\mathrm{GA}_{3}$ used in onion plants with 20-60 ppm played a similar role in increasing the root length compared to control. The increased root length due to $\mathrm{GA}_{3}$ might have resulted from the cell growth and cell elongation and thus developed an elongated root system. This result is consistent with the previous findings for onion (Hye et al., 2002).

The bulb diameter $(4.30 \mathrm{~cm})$ under the influence of 60 ppm $\mathrm{GA}_{3}$ was sharply higher than that of bulbs treated with 0-40 ppm GA 3 which showed statically similar result (Table 2). It was noticed that $\mathrm{GA}_{3}$ did not affect significantly the bulb length. A minor bulb diameter increase under $\mathrm{GA}_{3}$ treatment was observed in the present study and might be attributed to cell growth and cell elongation (Table 2). This finding are in contrast with other studies which noted that $\mathrm{GA}_{3}$ can affect the growth and development of bulb crops as well as promoting bulb diameter (Hye et al., 2002; Islam et al., 2007; Nagwa et al., 2013), in tomato (Choudhury et al., 2013) and in gladiolus (Sarkar et al., 2014).

\section{Fresh biomass assimilation}

The effect of different concentrations of $\mathrm{GA}_{3}$ on fresh root biomass was insignificant, whereas the significant effect was observed in both parameters of fresh shoot biomass and fresh bulb biomass of onion (Fig. 3). Different concentrations of $\mathrm{GA}_{3}$ had a significant effect on fresh shoot and fresh bulb biomass which were sharply increased to about $641.67 \mathrm{gm}^{-2}$ and $1125.00 \mathrm{gm}^{-2}$ respectively, with the application of $60 \mathrm{ppm} \mathrm{GA}_{3}$ in comparison to the other concentrations of $\mathrm{GA}_{3}$ (Fig. 3). Plants grown in control plot obtained the minimum fresh biomass at harvesting time in the shoot $\left(441.67 \mathrm{gm}^{-2}\right)$ and bulb $\left(641.67 \mathrm{gm}^{-2}\right)$.

As represented in Fig. 3, the study revealed that fresh shoot and fresh bulb biomass assimilation in onion were markedly increased due to the significant effect of $\mathrm{GA}_{3}$ while it was observed that $\mathrm{GA}_{3}$ did not affect significantly the fresh root biomass assimilation compared to control. It

Table 2. The influence of various doses of $\mathrm{GA}_{3}$ on root length, bulb length and bulb diameter at harvest time in onion

\begin{tabular}{|c|c|c|c|}
\hline Factors & Root length $(\mathrm{cm})$ & Bulb length $(\mathrm{cm})$ & Bulb diameter $(\mathrm{cm})$ \\
\hline $\mathrm{G}_{0}$ & $3.80 \pm 0.20^{\mathrm{b}}$ & $3.23 \pm 0.23^{a}$ & $3.10 \pm 0.06^{6}$ \\
\hline $\mathrm{G}_{20}$ & $5.63 \pm 0.20^{\mathrm{a}}$ & $3.53 \pm 0.34^{\mathrm{a}}$ & $3.43 \pm 0.09^{b}$ \\
\hline $\mathrm{G}_{40}$ & $6.00 \pm 0.12^{\mathrm{a}}$ & $3.87 \pm 0.26^{a}$ & $3.63 \pm 0.15^{b}$ \\
\hline $\mathrm{G}_{60}$ & $6.10 \pm 0.21^{\mathrm{a}}$ & $4.03 \pm 0.03^{\mathrm{a}}$ & $4.30 \pm 0.20^{\mathrm{a}}$ \\
\hline Df & 3 & 3 & 3 \\
\hline F-value & 33.52 & 2.13 & 14.17 \\
\hline P-value & 0.0001 & 0.1745 & 0.0014 \\
\hline
\end{tabular}

Means with the same letter did not significantly differ from each other at $\mathrm{p}<0.05$. Abbreviations are as follows, G0; 0, G20; 20, G40; 40 and G60; 60 ppm GA3 respectively.

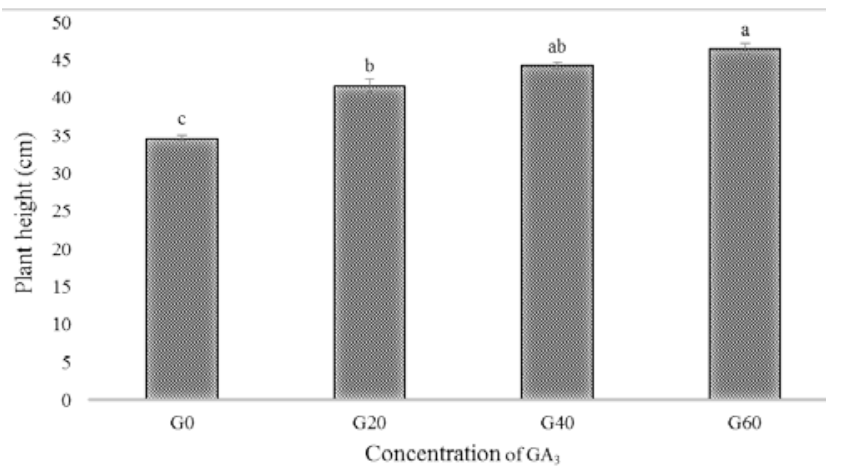

Fig. 1. Effect of various doses of $\mathrm{GA}_{3}$ on onion plants height at harvest. Vertical bars represent means \pm standard error mean. Means with the same letter did not significantly differ from each other at $p<0.05$. Abbreviations are as follows, $G_{0} ; 0, G_{20}$; $20, \mathrm{G}_{40} ; 40$ and $\mathrm{G}_{60} ; 60$ ppm $\mathrm{GA}_{3}$ respectively
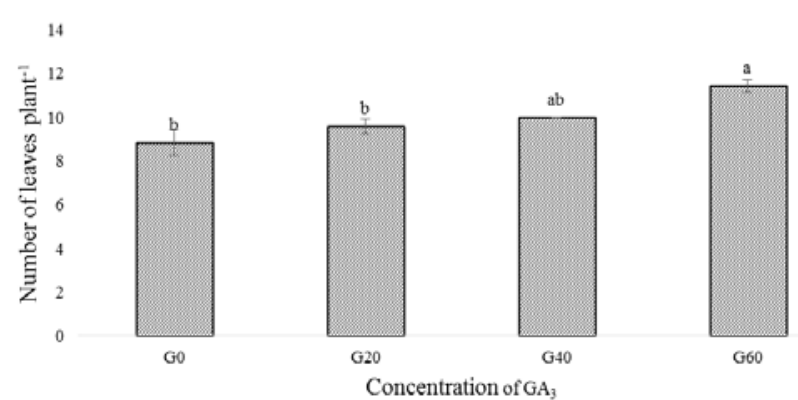

Fig. 2. Effect of various doses of $\mathrm{GA}_{3}$ on the number of leaves at onion harvest. Vertical bar represents means \pm standard error mean. Means with the same letter did not significantly differ from each other at $p<0.05$. Abbreviations are as follows, G0; 0, G20; 20, G40; 40 and G60; 60 ppm GA3 respectively 
36

might be a suitable factor for fresh biomass assimilation in shoot and bulb resulted from the effect of cell expansion growth, increased proline accumulation, reduced ABA content and balancing hormonal activity, which led to vigorous plant growth, leaf growth, number of leaves, thickness of pseudo-stem where plant get larger surface area for photosynthesis which ultimately expands the bulb growth. The present findings are in agreement with the previous reports for onion (Hye et al., 2002; Islam et al., 2007; Yamaguchi, 2008; Yu et al., 2009; Ouzounidou et al., 2011; Nagwa et al., 2013).

\section{Dry biomass accumulation}

Different concentrations of $\mathrm{GA}_{3}$ showed the insignificant effect on dry root biomass accumulation in onion, whereas dry shoot and dry bulb biomass accumulation was significant (Table 3). Considerably higher dry shoot biomass accumulation was observed in 60 ppm $\mathrm{GA}_{3}$ treated plants. This accumulation was of about 41.63\% compared with control.

With the increasing trend in $\mathrm{GA}_{3}$ concentration, there was an increase in dry biomass accumulation for onion shoots and bulbs, while it was perceived that $\mathrm{GA}_{3}$ did not affect significantly the dry root biomass accumulation (Table 3). It might be due to the effect of $\mathrm{GA}_{3}$ on increased vigorous plant growth, as well as leaf growth and shoot growth, where the onion plant obtained greater photosynthetic potentiality resulted in maximum photosynthates accumulation, which also redistributed towards the storage organ. Similar findings were reported for onion (Sharma et al., 1998; Ouzounidou et al., 2011; Nagwa et al., 2013).

Table 3. Influence of various doses of $\mathrm{GA}_{3}$ on dry biomass accumulation in onion shoots, bulbs and roots

\begin{tabular}{|c|c|c|c|}
\hline Factors & $\begin{array}{l}\text { Dry shoot biomass } \\
\qquad\left(\mathrm{g} \mathrm{m}^{-2}\right)\end{array}$ & $\begin{array}{l}\text { Dry bulb biomass } \\
\qquad\left(\mathrm{g} \mathrm{m}^{-2}\right)\end{array}$ & $\begin{array}{l}\text { Dry root biomass } \\
\qquad\left(\mathrm{g} \mathrm{m}^{-2}\right)\end{array}$ \\
\hline $\mathrm{G}_{0}$ & $42.42 \pm 3.18^{b}$ & $137.25 \pm 2.83^{b}$ & $12.33 \pm 0.79^{\mathrm{a}}$ \\
\hline $\mathrm{G}_{20}$ & $69.42 \pm 4.17^{a}$ & $151.83 \pm 6.63^{\mathrm{b}}$ & $12.33 \pm 0.79^{a}$ \\
\hline $\mathrm{G}_{40}$ & $71.17 \pm 4.99^{\mathrm{a}}$ & $174.08 \pm 2.59^{\mathrm{ab}}$ & $13.25 \pm 0.50^{a}$ \\
\hline $\mathrm{G}_{60}$ & $72.67 \pm 7.58^{\mathrm{a}}$ & $197.83 \pm 5.53^{\mathrm{a}}$ & $14.67 \pm 0.92^{\mathrm{a}}$ \\
\hline Df & 3 & 3 & 3 \\
\hline F-value & 7.54 & 8.34 & 2.06 \\
\hline P-value & 0.0102 & 0.0146 & 0.1835 \\
\hline
\end{tabular}

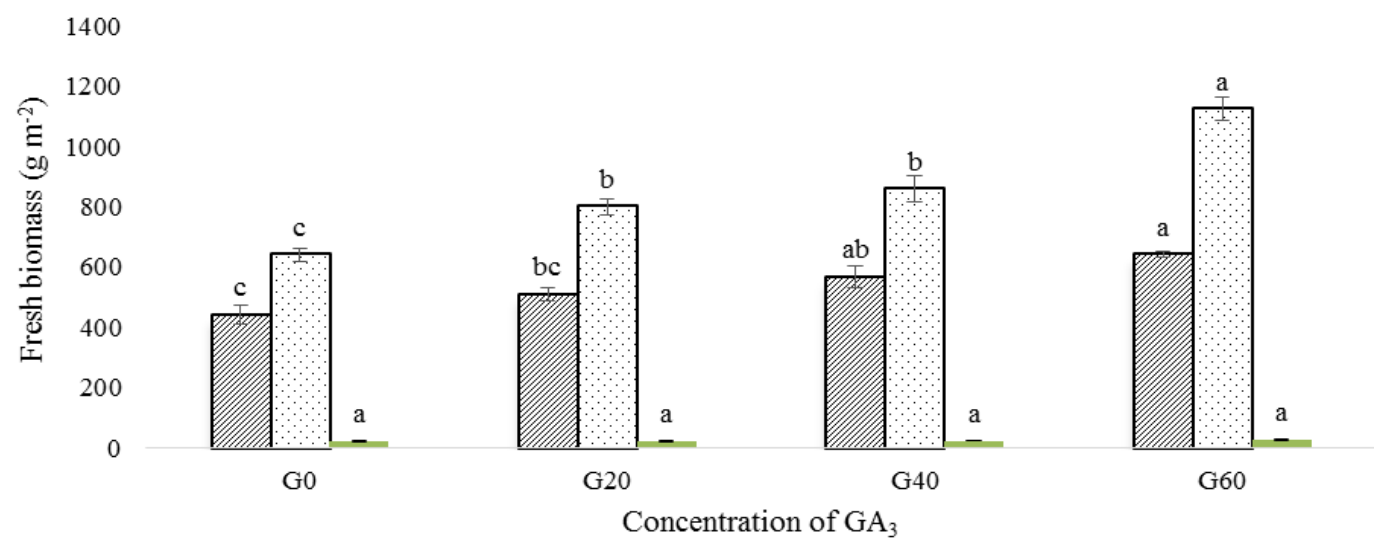

Fig. 3. Effect of $\mathrm{GA}_{3}$ on fresh shoots, bulbs and root biomass at harvest time in onion. Vertical bar represents means \pm standard error mean. Means with the same letter did not significantly differ from each other at $p<0.05$. Abbreviations are as follows, $G_{0} ; 0$, $\mathrm{G}_{20} ; 20, \mathrm{G}_{40} ; 40$ and $\mathrm{G}_{60} ; 60$ ppm $\mathrm{GA}_{3}$ respectively

\section{Conclusions}

Positive significant influence of $\mathrm{GA}_{3}$ was associated with onion plants' growth and physiological attributes. The use of $\mathrm{GA}_{3}$ at a dose of $60 \mathrm{ppm}$ provided better results than the other three concentrations tested, due to its influence on growth characters of the plants, which offer significantly higher yield potential in onion.

\section{References}

Amal MES, Hegazi AM (2009). Effect of acetylsalicylic acid, indole-3- bytric acid and gibberellic acid on plant growth and yield of pea (Pisum sativum L.). Australian Journal of Basic and Applied Sciences 3(4):35143523.

Ashraf M, Akram NA, Arteca RN, Foolad MR (2010). The physiological, biochemical and molecular roles of brassinosteroids and salicylic acid in 
plant processes and salt tolerance. Critical Reviews in Plant Sciences 29(3):162-190.

BBS (2015). Statistical Year Book Bangladesh ( $35^{\text {th }}$ ed). Bangladesh Bureau of Statistics: Ministry of Planning, Govt. People's Republic of Bangladesh pp 1-559. http: //203.112.218.65 /WebTestApplication /userfiles/Image/SubjectMatterDataIndex/YearBook15.pdf

Choudhury S, Islam N, Sarkar MD, Ali MA (2013). Growth and yield of summer tomato as influenced by plant growth regulators. International Journal of Sustainable Agriculture 5(1):25-28.

FRG (2012). Fertilizer recommendation guide, Bangladesh Agricultural Research Council, Farmgate, Dhaka pp 1-274.

Ghoname AA, Salah SA, Riad GS, Fawzy ZF, El-Abd SO (2011). Enhancement of carrot seed yield and quality by root dipping in gibberellic acid. Journal of Applied Sciences Research 7(12):1821-1827.

Hye MA, Haque MA, Karim A (2002). Influence of growth regulators and their time of application on yield of onion. Pakistan Journal of Biological Sciences 5(10):1021-1023.

Islam S, Islam MO, Alam MN, Ali MK, Rahman MA (2007). Effect of plant growth regulator on growth, yield and yield components of onion. Asian Journal of Plant Sciences 6(5):849-853.

Jones AMP, Saxena PK, Murch SJ (2009). Elicitation of secondary metabolism in Echinacea purpurea L. by gibberellic acid and triazoles. Engineering in Life Sciences 9(3):205-210.

Nagwa MKH, Shafeek MR, Saleh SA, Nadia HMEG (2013). Growth, yield and nutritional values of onion (Allium cepa $\mathrm{L}$.) plants as affected by bioregulators and Vitamin $\mathrm{E}$ under newly reclaimed lands. Journal of Applied Sciences Research 9(1):795-803.

Olszewski N, Sun TP, Gubler F (2002). Gibberellin signaling: Biosynthesis, catabolism, and response pathways. Plant Cell 14:561-580.

Ouzounidou G, Giannakoula A, Asfi M, Ilias I (2011). Differential response of onion and garlic agenest plant growth regulator. Pakistan Journal of Botany 43(4):2051-2057.

Pérez-Jiméneza M, Pazos-Navarrob M, López-MarínaJ, Gálveza A, VarócP, Amor FMd (2015). Foliar application of plant growth regulators changes the nutrient composition of sweet pepper (Capsicum annuum L.). Scientia Horticulturae 194:188-193.

Rahman S, Islam A, Haque S, Karim A (2004). Effect of planting date and gibberellic acid on the growth and yield of garlic. Asian Journal of Plant Sciences 3(3):344-352
Sarkar MAH, Hossain MI, Uddin AFMJ, Uddin MAN, Sarkar MD (2014). Vegetative, floral and yield attributes of gladiolus in response to gibberellic acid and corm size. Scientia Agriculturae 3:142-146.

Sharma K, Rok Lee Y, Park SW, Nile SH (2015). Importance of growth hormones and temperature for physiological regulation of dormancy and sprouting in onions. Food Reviews International 32(3):233-255.

Sharma N, Kaur N, Gupta AK (1998). Effects of gibberellic acid and chlorocholine chloride on tuberisation and growth of potato (Solanum tuberosum L.). Journal of the Science of Food and Agriculture 78(4):466-470.

Shukla N, Mondal S, Dikshit SN, Trivedi J, Tamrakar S, Sharma P (2010). Effect of different concentrations of $\mathrm{GA}_{3}$ and NAA and their methods of application on growth and yield of onion (Allium cepa $\mathrm{L}$.). Progressive Horticulture 42(1):111-113.

Sisodia A, Nagaich KN, Singh AK (2012). Effect of nitrogen and $\mathrm{GA}_{3}$ on growth, yield and yield attributes in onion (Allium cepa) Cv. Nasik red. Annals of Horticulture 5(2):293-297.

Sultana S, Amin MR, Hossain MI, Sarkar MD (2016). Response of GA A $_{3}$ to morphological characteristics of tuberose incorporated with organic manures. International Journal of Scientific and Research Publications 6(12):384388.

Taiz L, Zeiger E (2010). Plant Physiology, 5th Ed. Sinauer Associates Inc., Sunderland, Massachusetts USA.

Ubeda Tomas S, Federici F, Casimiro I, Beemster GT, Bhalerao R (2009). Gibberellin signaling in the endodermis controls arabidopsis root meristem size. Current Biology 19(14):11941199.

Ud-deen MM (2009). Effect of plant growth regulators on growth and yield of Mukhi Kachu. Bangladesh Journal of Agricultural Research 34(2):233-238.

Ud-Deen MM, Kabir G, Rahman MA, Hossain MS (2005). Influence of plant growth regulators on morphological changes in onion (Allium ceoa L.). Bangladesh Journal of Environmental Science 11(1):94-96.

Yamaguchi S (2008). Gibberellin metabolism and its regulation. Annual Review of Plant Biology 59:225-251.

Yu K, Wei J, Ma Q, Yu D, Li J (2009). Senescence of aerial parts is impeded by exogenous gibberellic acid in herbaceous perennial Paris polyphylla. Journal of Plant Physiology 166(8):819-830. 